\title{
Crude corn oil with high acidity in broiler feed
}

\section{Óleo bruto de milho com alta acidez em rações para frangos de corte}

\author{
Sâmela Keila Almeida dos Santos ${ }^{1 *}$; Flávia de Sousa Gomes Crosara ${ }^{1}$; Fernanda \\ Heloisa Litz ${ }^{1}$; Carolina Magalhães Caires Carvalho²; Veridiana Aparecida Limão; \\ Lúcio Vilela Carneiro Girão ${ }^{3}$; Ana Luísa Neves Alvarenga Dias ${ }^{3}$; Tatiane Alves \\ de Moraes ${ }^{4}$; Larissa Christine Gosuen Mariano de Souza ${ }^{5}$; Evandro de Abreu \\ Fernandes ${ }^{3}$
}

\begin{abstract}
This study aimed to evaluate crude corn oil with high acidity (CCOHA) as a surrogate for degummed soybean oil (DSO) in broiler diets. The design was completely randomized, with four treatments and ten replicates. Each box contained 40 birds (male), totaling 1600 Cobb Slow birds. Treatments consisted of two sorghum-based diets, one with DSO (SSO) another with CCOHA (SCO), and two corn-based diets, one with DSO (CSO) another with CCOHA (CCO). At 30 days of age, a digestibility test was performed using total excreta collection to determine apparent metabolizable energy (AME) and nitrogen-corrected AME (AMEn) from test rations. At 42 days of age, we evaluated live weight (LW), feed intake (FI), feed conversion (FC), carcass yield (CY), and the yields of breast with bone and skin (BWBS), skinless boneless breast (SBB), thigh (T), drumstick (D), and wing (W), as well as breast centesimal composition. Neither corn nor sorghum-based diets with CCOHA showed differences between AME and AMEn. Both DSO and CCOHA diets showed no differences in LW, FI, FC, carcass and cuts yields when using CCOHA. Regarding breast composition, no differences in dry matter and in the levels of crude protein, fat, and mineral matter were observed. We may conclude that CCOHA had no effect on the performance variables, carcass and cuts yields, and broiler meat quality.
\end{abstract}

Key words: Feed conversion. Co-product. Metabolizable energy. Carcass yield.

\section{Resumo}

Objetivou-se avaliar a inclusão do óleo bruto de milho com alta acidez (OBMAA) em substituição ao óleo degomado de soja (ODS) em rações para frangos de corte. O delineamento foi inteiramente casualizado, sendo quatro tratamentos com dez repetições, cada boxe com 40 aves (machos), totalizando 1600 aves da linhagem Cobb Slow. Os tratamentos foram: ração base sorgo com ODS (SOS), ração base sorgo com OBMAA (SOM), ração base milho com ODS (MOS) e ração base milho com OBMAA (MOM). Aos 30 dias de idade foi realizado um ensaio de digestibilidade por meio de coleta total de excretas, para a determinação dos valores de energia metabolizável aparente (EMA) e energia metabolizável aparente corrigida pelo balanço de nitrogênio (EMAn) nas rações teste. Ao final dos 42 dias determinou-se o

\footnotetext{
${ }^{1}$ Discentes de Doutorado em Ciências Veterinárias, Faculdade de Medicina Veterinária, FAMEV, Universidade Federal de Uberlândia, UFU, Uberlândia, MG, Brasil. E-mail: samela-zootecnia@hotmail.com; flaviasgvet@gmail.com; fernandalitz@ veterinaria.med.br; verilimao@gmail.com

2 Dra , Zootecnista, FAMEV/UFU, Uberlândia, MG, Brasil. E-mail: carollcaires@yahoo.com.br

3 Profs. Drs., FAMEV/UFU, Uberlândia, MG, Brasil. E-mail: luciogirao@ufu.br; analuisa@ufu.br; evandro.fernandes@ufu.br

4 Discente Graduação em Zootecnia, FAMEV, UFU, Uberlândia, MG, Brasil. E-mail: tatianemoraisalves@gmail.com

5 Discente em Medicina Veterinária, FAMEV, UFU, Uberlândia, MG, Brasil. E-mail: larissagousuen_711@hotmail.com

* Author for correspondence
} 
peso vivo (PV), consumo de ração (CR), conversão alimentar (CA) e rendimento de carcaça (RC), peito com osso e pele (PCOP), peito sem osso e pele (PSOP), coxa (C), sobrecoxa (SC) e asas (A) e composição centesimal do peito. Não houve diferença nos valores de energia metabolizável aparente (EMA) e energia metabolizável aparente corrigida pelo balanço de nitrogênio (EMAn) das rações base milho e base sorgo com OBMAA. O uso do OBMAA não diferiu sobre o PV, CR, CA e rendimentos de carcaça e cortes tanto nas dietas com o ODS quanto nas com OBMAA. Na composição de peito, não houve diferença de matéria seca e nos teores de proteína bruta, gordura e de matéria mineral. Conclui-se que o OBMAA não afetou as variáveis de desempenho, rendimento de carcaça e corte e a qualidade da carne de frangos de corte.

Palavras-chave: Conversão alimentar. Coproduto. Energia metabolizável. Rendimento de carcaça.

\section{Introduction}

Chicken meat is an important animal protein for human consumption. In times of great population growth worldwide, the poultry industry has tried to adapt itself to new technologies able to enhance production at lower costs (OLIVEIRA et al., 2006).

In the poultry chain, the highest costs come from animal nutrition; such expenses can exceed $70 \%$ of the total costs (INNOCENTINI, 2009), within which energy accounts for most of this cost (VASCONCELLOS et al., 2011). In this respect, we seek alternative energy sources with a lower market value and quality equal to or higher than the traditional ones.

Oils and fats are frequently used in broiler nutrition because they provide an increase in energy density, with a lower caloric increment compared to other nutrients, thereby promoting a beneficial effect on poultry performance (SAKOMURA et al., 2004). In other words, they help in the energy balance of diets by providing readily-available energy for consumption, enhancing nutrient absorption and slowing down food passage (BERTECHINI, 2012). Soybean oil is the most used in the broiler industry; however, oscillations in the prices make producers seek alternative ingredients to reduce costs (BOSA et al., 2012).

Bearing in mind these factors, crude corn oil with high acidity (CCOHA) has been considered as an alternative substitute for soybean oil. CCOHA has arisen as a result of the growing corn-to-ethanol industry, being processed in some sugarcane plants during the inter-crop period. This oil may have a high potential for use in rations for poultry and other monogastric animals, replacing lipid sources. It is worth noting that the use of regional products, such as agroindustrial co-products, can make production costs even more feasible, in relation to transport and acquisition (RODRIGUES FILHO; AZEVEDO, 2006). These co-products do not compete with human food (ZAMBOM et al., 2001) and, if used, they do not accumulate in the environment, especially in the soil and water, contributing to sustainable animal production and preserving natural resources (BRAS et al., 2014). Studies have shown that these agroindustrial co-products can provide about 3 trillion Mcal of metabolizable energy (ME) per year (GOES et al., 2008). Therefore, the CCOHA has become an option of energetic ingredient for the formulation of broiler ration, being able to act on both the performance and the quality of the carcass (VIEIRA et al., 2002).

Based on the above, the objective of this study was to test crude corn oil with high acidity (CCOHA) as a substitute for degummed soybean oil (DSO) in broiler rations, evaluating metabolizable energy, performance, carcass yield, and breast-muscle centesimal composition.

\section{Material and Methods}

The experiment was conducted according to ethical standards and approved by the Ethics Committee on Animal Use (CEUA-UFU), under Research Protocol No. 134/16. It was carried out 
at the Bird Experimentation Farm of the Federal University of Uberlândia (AVIEX-UFU), between the months of August and September of 2016.

A total of 1600 Cobb Slow males were housed from the first day of age to the 42nd day of age. In all the breeding phases, the management practices followed the model practiced in the experimental farm of the Federal University of Uberlândia, which resemble the practices of the industrial poultry management of the region, associated to the one recommended by the bird strain manual. The natural-artificial light program, according to the strain manual, consisted of two hours of darkness in the first two weeks, four hours of darkness in the third week, and one hour of darkness until the sixth week. The feeding program had four phases: prestarter ration (1-7 days), starter ration (8-21 days), fattening ration (22-35 days), and slaughter ration (36-42 days). Birds received ration and drinking water ad libitum.

A completely randomized design was used, which comprised four treatments with ten replicates (boxes of $1.90 \times 1.50 \mathrm{~m}$ each), each box containing a total of 40 birds ( 14 birds / $\mathrm{m} 2$ ), totaling 400 birds per treatment. Treatments were distributed as follows: sorghum-based diet with degummed soybean oil (SSO), a sorghum-based diet with CCOHA (SCO), a corn-based diet with degummed soybean oil (CSO), and corn-based diet with CCOHA (CCO).

The diets of each phase were isoenergetic and isonutritive, produced with corn or sorghum, soybean meal, degummed soybean oil (DSO) or crude corn oil with high acidity (CCOHA), dicalcium phosphate, limestone, $\mathrm{NaCl}$ (cooking salt), and vitamin premix (Table 1). The ingredients were submitted to a bromatological analysis for diet formulation support. The diets were formulated based on degummed soybean oil energy value (8786 kcal $/ \mathrm{kg}$ ) (ROSTAGNO et al., 2011). The exchange for an equal amount of crude corn oil with high acidity, in those treatments with $\mathrm{CCOHA}$, occurred during ingredient mixing for each grain (sorghum and corn). At 30 days of age, fattening ration metabolizable energy was measured based on total excreta collection method (SIBBALD; SLINGER, 1963) using chickens from the same study (SIBBALD; SLINGER, 1963). The treatments were arranged in a completely randomized design, where average-weight animals were housed in metabolic cages (two in each), comprising three treatments and five replicates per treatment. The control ration was corn-based with DSO (CSO) and was then compared to the rations from the performance experiment: corn-based with $\mathrm{CCOHA}$ (CCO) and sorghum-based with CCOHA (SCO). After three days of adaptation to the cages and diet, excreta collection was started and performed for five consecutive days. A fixed amount of feed was weighed at the start of the test and the total feed intake was calculated at the end of it.

The excreta were collected twice a day and stored in a freezer. At the end of the test, the feces were thawed and together with a sample of the rations were sent to the Laboratory of Animal Nutrition of the Federal University of Uberlândia for the bromatological analysis. The apparent metabolizable energy (AME) and nitrogencorrected apparent metabolizable energy (AMEn) were determined (MATTERSON et al., 1965) from gross energy values of the diets and the excreta using IKA C2000 basic bomb calorimeter. 
Tabela 1. Composition and nutritional levels of the experimental diets used in the following treatments.

\begin{tabular}{|c|c|c|c|c|}
\hline \multirow{2}{*}{ Nutritional Levels } & \multicolumn{4}{|c|}{ Ration } \\
\hline & Pre-starter & Initial & Fattening & Slaughter \\
\hline ME (kcal kg-1) & 2.955 & 3.054 & 3.152 & 3.200 \\
\hline Crude protein (\%) & 22.40 & 21.20 & 19.90 & 18.90 \\
\hline Calcium $(\%)$ & 0.93 & 0.83 & 0.75 & 0.65 \\
\hline Available phosphorous(\%) & 0.46 & 0.39 & 0.35 & 0.30 \\
\hline Sodium $(\%)$ & 0.22 & 022 & 0.22 & 0.21 \\
\hline Digest. met. (\%) & 0.66 & 0.60 & 0.56 & 0.51 \\
\hline Methionine+Cystine & 0.95 & 0.87 & 0.82 & 0.76 \\
\hline Digest. threonine (\%) & 0.85 & 0.78 & 0.72 & 0.68 \\
\hline Digestible lysine (\%) & 1.30 & 1.20 & 1.11 & 1.04 \\
\hline Digest. tryptophan(\%) & 0.24 & 0.23 & 0.22 & 0.21 \\
\hline \multirow{2}{*}{ Ingredients } & \multicolumn{4}{|c|}{ Sorghum-based Diets (\%) } \\
\hline & Pre-starter & Initial & Fattening & Slaughter \\
\hline Sorghum 8.5 & 54.73 & 56.80 & 60.14 & 63.30 \\
\hline Soybean meal $46.5 \%$ & 37.28 & 34.67 & 30.65 & 27.74 \\
\hline $\mathrm{DSO} / \mathrm{CCOH}^{2}$ & 3.69 & 4.81 & 5.75 & 5.89 \\
\hline Dicalcium phosphate & 1.89 & 1.52 & 1.32 & 1.06 \\
\hline Calcarium & 0.89 & 0.83 & 0.78 & 0.71 \\
\hline Salt & 0.46 & 0.46 & 0.44 & 0.45 \\
\hline DL-methionine & 0.21 & 0.16 & 0.16 & 0.20 \\
\hline L-lysine $\mathrm{HCl}$ & 0.31 & 0.26 & 0.27 & 0.28 \\
\hline MC-Mix mineral and vit. ${ }^{1}$ & 0.40 & 0.40 & 0.40 & 0.30 \\
\hline L-Threonine & 0.13 & 0.09 & 0.09 & 0.08 \\
\hline \multirow{2}{*}{ Ingredients } & \multicolumn{4}{|c|}{ Corn-based diets (\%) } \\
\hline & Pre-starter & Initial & Fattening & Slaughter \\
\hline Ground corn 8.2 & 57.32 & 59.50 & 61.28 & 64.30 \\
\hline Soybean meal $46.5 \%$ & 36.88 & 34.07 & 31.52 & 28.85 \\
\hline $\mathrm{DSO} / \mathrm{CCOH}^{2}$ & 1.75 & 2.83 & 3.95 & 4.04 \\
\hline Dicalcium phosphate & 1.78 & 1.41 & 1.20 & 0.93 \\
\hline Calcarium & 0.84 & 0.90 & 0.84 & 0.77 \\
\hline Salt & 0.45 & 0.45 & 0.43 & 0.43 \\
\hline DL-methionine & 0.18 & 0.13 & 0.12 & 0.13 \\
\hline L-lysine $\mathrm{HCl}$ & 0.28 & 0.24 & 0.20 & 0.19 \\
\hline MC-Mix mineral and vit. ${ }^{1}$ & 0.40 & 0.40 & 0.40 & 0.30 \\
\hline L-Threonine & 0.11 & 0.08 & 0.05 & 0.04 \\
\hline
\end{tabular}

${ }^{1}$ MC-Mix Starter (composition per kilogram of feed): - Methionine : 420.75g; Choline: 65,25g; Vit A: 2750000UI; Vit D3: 500000UI; Vit E: 4000UI; Vit K3: 375mg; Vit B1:300mg; Vit B2: 1125mg; Vit B6: 500mg; Vit B12: 4000mcg; Niacin: 8750mg; Pantothenic Acid: 2300mg; Folic Acid: 100mg; Biotin: 15mg; Fe: 7500mg; Cu: 2250mg; Mn: 15g; Zn: 15g; I: 250mg; Se: 62,5mg; Enramycin: 2500mg; Narasin:12,5g/Nicarbazin:12,5mg. MC-Mix Fattening (composition per kilogram of feed) - Methionine: 386,1g; Choline: 54,81g; Vit A: 2250000UI; Vit D3: 400000UI; Vit E: 3500UI; Vit K3: 375mg; Vit B1:250mg; Vit B2: 1000mg; Vit B6: 450mg; Vit B12: 3000mcg; Niacin: 7500mg; Pantothenic Acid: 2070mg; Folic Acid: 75mg; Biotin: 12,5mg; Fe: 7500mg; Cu: 2250mg; Mn: 15g; Zn: 15g; I: 250mg; Se: 62,5mg; Avilamycin: 2500mg; Salinomycin: 15g. MC-Mix Slaughter (composition 
per kilogram of feed): Methionine: 301,95g; Choline: 43,48g; Vit A: 900000UI; Vit D3: 150000UI; Vit E: 1500UI; Vit K3: 150mg; Vit B1:90mg; Vit B2: 300mg; Vit B6: 120mg; Vit B12: 900mcg; Niacin: 1500mg; Pantothenic Acid: 1104mg; Biotin: 4,5mg; Fe: 10g; Cu: 3000mg; Mn: 20g; Zn: 20g; I: 333,33mg; Se: 60mg. ${ }^{2}$ DSO: Degummed Soybean Oil; CCOHA: Crude Corn Oil with High Acidity.

At 42 days of age, birds and ration leftovers were weighed for performance evaluation: live weight (LW), feed intake (FI) and feed conversion (FC). At the end of the experiment, 10 birds with average weight, within each treatment $(+/-2.5 \%)$, were euthanized after an 8-hour fasting for evaluations on carcass yield (CY) and the yields of breasts with bone and skin (BWBS), skinless boneless breasts (SBB), thighs (T), drumsticks (D), and wings (W). These parameters were calculated in relation to slaughter live weight using the following formulas: $\% \mathrm{CY}=($ Carcass weight $\mathrm{x} 100) /$ Live Weight; Cuts yield $=($ Part weight $x$ 100) $/$ Live Weight.

The breast was separated, identified, frozen, and then taken to the laboratory for centesimal composition analysis. The samples were ground and homogenized, placed in aluminum trays, and then dried in a forced ventilation oven at $55^{\circ} \mathrm{C}$ for 72 hours; thereafter, dry matter (DM) was weighed. After drying, they were processed in a knife mill and fractionated into samples for crude protein (CP) and mineral matter $(\mathrm{MM})$ determinations under the terms in the Brazilian Compendium of Animal Nutrition (BRASIL, 2005). Fat content (F) was estimated by the differences between $\mathrm{CP}$ and MM contents in DM. These data were presented on a dry basis.

The variables were checked for normality and submitted to analysis of variance (ANOVA), and treatment means were compared by the Tukey's test at 5\% significance, using SISVAR software (FERREIRA, 2011).

\section{Results and Discussion}

The results of feed intake (FI), live weight (LW) and feed conversion (FC) are presented in Table 2. For all the tested rations, the FC of diets with DSO and CCOHA showed no difference ( $\mathrm{P}>0.05)$. Exchanging DSO for CCOHA in all treatments did not interfere with LW of birds. Therefore, the nutritional requirements were met and chickens were able to benefit from all the ingredients in the diet. Moreover, CCOHA had no influence on the FC of birds. In fact, this variable was expected to present such behavior since there were no changes for both FI and LW, which are variables used to calculate FC.

Table 2. Feed intake (FI), live weight (LW) and feed conversion (FC) of broilers at 42 days, submitted to diets containing degummed soybean oil or crude corn oil with high acidity.

\begin{tabular}{cccc}
\hline Treatment & FI $(\mathrm{kg} / \mathrm{cab})$ & $\mathrm{LW}(\mathrm{kg} / \mathrm{cab})$ & $\mathrm{FC}(\mathrm{kg}: \mathrm{kg})$ \\
\hline $\mathrm{SSO}^{1}$ & 5.15 & 3.14 & 1.640 \\
$\mathrm{SCO}^{2}$ & 5.12 & 3.12 & 1.631 \\
$\mathrm{CSO}^{3}$ & 5.03 & 3.08 & 1.633 \\
$\mathrm{CCO}^{4}$ & 5.05 & 3.05 & 1.655 \\
\hline -value & 0.5592 & 0.0896 & 0.7373 \\
$\mathrm{CV} \%$ & 3.38 & 5.79 & 4.23 \\
\hline
\end{tabular}

${ }^{1} \mathrm{SSO}$ : Sorghum-based diet with degummed soybean oil. ${ }^{2} \mathrm{SCO}$ : Sorghum-based diet with CCOHA. ${ }^{3} \mathrm{CSO}$ : Corn-based diet with degummed soybean oil. ${ }^{4} \mathrm{CCO}$ : Corn-based diet with CCOHA.

Means followed by different letters in the line differ by Tukey test $5 \%(\mathrm{p}<0.05)$. 
Studying different oil sources (linseed, sardine, and soybean) in broiler ration, Pinto et al. (2014) observed no differences for FC in 42-day-old birds, as observed here with CCOHA. This result shows the potential use of CCOHA in the feed industry for broilers; therefore, vegetable lipid sources, as well as this co-product, can be used in poultry rations without compromising broiler performance. An interference with performance parameters is mainly related to lipid composition of free fatty acids and to the product processing (FERNANDES et al., 2002).
As shown in Table 3, all rations provided equal values $(\mathrm{P}>0.05)$ for carcass $(\mathrm{CY})$, breast with bone and skin (BWBS), and skinless boneless breast (SBB) yields. As there were no differences in the performance parameters of these birds, no changes were expected regarding carcass yield. Furthermore, since the difference between rations was basically CCOHA inclusion, this oil had no influence on carcass yield (CY), and on yields of breast with bone and skin (BWBS) and skinless boneless breast (SBB). This is a positive factor since it is feasible to use this component as an alternative at times of the year when other lipid source prices are high.

Table 3. Carcass yield and cuts (\%) of broilers at 42 days, submitted to diets containing degummed soybean oil or crude corn oil with high acidity.

\begin{tabular}{ccccccc}
\hline Treatment & $\% \mathrm{CY}^{5}$ & \%BWBS & \%SBB & $\% \mathrm{~T}^{8}$ & $\% \mathrm{D}^{9}$ & $\% \mathrm{~W}^{10}$ \\
\hline $\mathrm{SSO}^{1}$ & 82.14 & 30.13 & 23.61 & 9.15 & 12.24 & 8.15 \\
$\mathrm{SCO}^{2}$ & 83.30 & 29.21 & 22.55 & 9.38 & 12.35 & 8.45 \\
$\mathrm{CSO}^{3}$ & 82.97 & 29.98 & 22.47 & 9.48 & 11.94 & 8.37 \\
$\mathrm{CCO}^{4}$ & 83.21 & 29.94 & 22.69 & 9.38 & 12.23 & 8.11 \\
\hline$P$-value & 0.634 & 0.372 & 0.500 & 0.670 & 0.516 & 0.332 \\
$\mathrm{CV} \%$ & 2.78 & 3.29 & 2.64 & 4.13 & 3.84 & 5.18 \\
\hline
\end{tabular}

${ }^{1} \mathrm{SSO}$ : Sorghum-based diet with degummed soybean oil sorgo. ${ }^{2} \mathrm{SCO}$ : sorghum-based diet with CCOHA. ${ }^{3} \mathrm{CSO}$ : corn-based diet with degummed soybean oil. ${ }^{4} \mathrm{CCO}$ : corn-based diet with CCOHA. ${ }^{5} \mathrm{CY}$ : Carcass yield.${ }^{6} \mathrm{BWBS}$ : The yields of breasts with bone and skin. ${ }^{7} \mathrm{SBB}$ : Skinless boneless breasts. ${ }^{8} \mathrm{~T}$ : Thighs. ${ }^{9} \mathrm{D}$ : Drumsticks. ${ }^{10} \mathrm{~W}$ : Wings.

Means followed by different letters in the line differ by Tukey test $5 \%(p<0.05)$

Duarte et al. (2010), studied the use of bovine tallow, poultry viscera oil, degummed soybean oil and mixtures of these oils for Cobb broilers at 41 days of age with corn-based diets and found no difference among carcass yields. Thus, once the free fatty acids have similar compositions, carcass yield will not be impaired regardless the oil source (animal or vegetable).

There was no difference $(\mathrm{P}>0.05)$ among the rations tested for yields of thighs $(\mathrm{T})$ and drumsticks (D) (Table 3). Likewise, Lara et al. (2006) found no differences for yields of these cuts in a study comparing soybean oil, viscera oil, and acid soybean oil for broilers at 45 days of age, confirming our study results with an acid oil (CCOHA). Wing yield (A) was not influenced by the tested rations. These results corroborate those found by Duarte et al. (2010), who obtained similar wing yields for broilers fed diets with vegetable and animal oil sources. Similarly, when using different proportions of linseed oil and soybean oil in broiler diets, no differences were observed between carcass and cuts yields (ALMEIDA et al., 2009).

Table 4 shows the centesimal composition of broiler breasts; the results showed no difference among rations $(\mathrm{P}>0.05)$ for breast dry matter. Moreover, contents of crude protein, fat, and mineral matter had no differences among diets. 
Muscle centesimal analysis displayed no difference between corn-based and sorghum-based rations, as well as between degummed soybean oil and crude corn oil with high acidity. Thus, CCOHA acidity did not compromise breast meat composition.

Table 4. Levels of dry matter (DM), crude protein (CP), mineral matter (MM) and fat content (G), of the pectoral muscle broilers at 42days, submitted to diets containing degummed soybean oil or crude corn oil with high acidity.

\begin{tabular}{ccccc}
\hline Treatment & $\mathbf{\% D M}^{\mathbf{5}}$ & $\mathbf{\% C P}^{\mathbf{5}}$ & $\mathbf{\% M M}^{\mathbf{5}}$ & $\mathbf{\% F}^{\mathbf{5}}$ \\
\hline $\mathrm{SSO}^{1}$ & 27.17 & 22.02 & 1.37 & 3.78 \\
$\mathrm{SCO}^{2}$ & 27.17 & 21.79 & 1.32 & 4.06 \\
$\mathrm{CSO}^{3}$ & 28.13 & 22.78 & 1.31 & 4.05 \\
$\mathrm{CCO}^{4}$ & 27.15 & 21.72 & 1.28 & 4.15 \\
\hline$P$-value & 0.6343 & 0.3725 & 0.6702 & 0.5771 \\
$C V \%$ & 5.23 & 3.25 & 4.19 & 6.39 \\
\hline
\end{tabular}

${ }^{1} \mathrm{SSO}$ : Sorghum-based diet with degummed soybean oil Sorgo. ${ }^{2} \mathrm{SCO}$ : sorghum-based diet with CCOHA. ${ }^{3} \mathrm{CSO}$ : corn-based diet with degummed soybean oil. ${ }^{4} \mathrm{CCO}$ : corn-based diet with CCOHA. ${ }^{5}$ Expressos na base seca.

Means followed by different letters in the line differ by Tukey test $5 \%(\mathrm{p}<0.05)$

These results differ from those found by Antunes et al. (2016), who compared degummed soybean oil and crude corn oil for broiler chickens and found different results for dry matter and crude protein in breasts, and similar results only for fat contents. On the other hand, these findings confirm the hypothesis of equal energy values between DSO and CCOHA.

No differences were found between AME and AMEn among experimental diets $(\mathrm{P}>0.05)$ (Table 5 ); hence, CCOHA could replace DSO in broiler diets. Notably, this test was carried out in a life stage at which birds are already able to digest fat, showing a high digestibility coefficient (FAGUNDES, 2011). Acid oils have lower values of metabolizable energy compared to neutral oils of the same origin; this is because these acid oils are predominantly composed of free fatty acids (VIEIRA et al., 2002). However, in the current study, corn-oil acidity comes from its processing, when a certain degree of hydrolysis occurs and possibly promote a better digestibility, contributing to this increased metabolizable energy. Another explanation for the similarity in energy values between CCOHA and DSO is the proper processing and storing of this oil type, which had no negative effect on its nutritional properties.

Table 5. Apparent metabolizable energy values (AME) and apparent metabolizable energy corrected for nitrogen balance (AMEn) of fattening diets.

\begin{tabular}{ccc}
\hline Tratamento & AME Kcal $/ \mathrm{kg}$ & AMEn Kcal $/ \mathrm{kg}$ \\
\hline $\mathrm{CSO}^{1}$ & 2.944 & 2.740 \\
$\mathrm{CCO}^{2}$ & 2.968 & 2.781 \\
$\mathrm{SCO}^{3}$ & 3.010 & 2.812 \\
\hline$P$-valor & 0.07 & 0.09 \\
$\mathrm{CV} \%$ & 1.26 & 1.73 \\
\hline
\end{tabular}

${ }^{1} \mathrm{CSO}$ : Corn-based diet with degummed soybean oil. ${ }^{2} \mathrm{CCO}$ : Corn-based diet with CCOHA. ${ }^{3} \mathrm{SCO}$ :Sorghum-based diet with CCOHA.

Means followed by different letters in the line differ by Tukey test $5 \%(\mathrm{p}<0.05)$ 


\section{Conclusion}

The metabolizable energy of crude corn oil with high acidity (CCOHA) and of degummed soybean oil (DSO) are similar. The CCOHA has a high potential to be classified as a co-product capable of fully replacing DSO, without compromising animal performance, carcass and cuts yields, and breast centesimal composition in 42-day-old broilers.

\section{References}

ALMEIDA, A. P. S.; PINTO, M. F.; POLONI, L. B.; PONSANO, E. H. G.; GARCIA NETO, M. Efeito do consumo de óleo de linhaça e de vitamina E no desempenho e nas características de carcaça de frangos de corte. Arquivo Brasileiro de Medicina Veterinária e Zootecnia, Belo Horizonte, v. 61, n. 3, p. 698-705, 2009.

ANTUNES, M. M.; BUENO, J. P. R.; FERNANDES, E. A.; CARVALHO, C. M. C.; LITZ, F. H.; MARTINS, J. M. S.; SILVA, M. C. A.; MASCULI, A. L. S.; NASCIMENTO, M. R. B. M. Effect of corn oil on the digestibility and economic viability of broiler chicken feed, and on the bromatological composition of breast meat. Semina Ciências Agrárias, Londrina, v. 37, n. 1, p. 429-438, 2016.

BERTECHINI, A. G. Nutrição de monogástricos. 2. ed. Lavras: UFLA Editora, 2012. 375 p.

BOSA, R.; FATURI, C.; VASCONCELOS, H. G. R.; CARDOSO, A. M.; RAMOS, A. F. O.; AZEVEDO, J. C. Consumo e digestibilidade aparente de dietas com diferentes níveis de inclusão de torta de coco para alimentação de ovinos. Acta Scientiarum. Animal Sciences, Maringá, v. 34, n. 1, p. 57-62, 2012.

BRÁS, P.; POSSENTI, R. A.; BUENO, M. S.; CANOVA, E. B.; SCHAMMAS, E. A. Avaliação nutricional de coprodutos da extração de óleos vegetais em dieta de ovinos. Boletim de Indústria Animal, Nova Odessa, v. 71, n. 2, p. 160-175, 2014.

BRASIL. Ministério da Agricultura e Abastecimento. Sindicato Nacional da Indústria de Alimentação Animal. Associação Nacional dos Fabricantes de Rações. Compêndio brasileiro de alimentação animal. São Paulo: ANFAR/CBNA/SDR, 2005. 204 p.

DUARTE, F. D.; LARA, L. J. C.; BAIÃO, N. C.; CANÇADO, S. V.; TEIXEIRA, J. L. Efeito da inclusão de diferentes fontes lipídicas em dietas para frangos de corte sobre o desempenho, rendimento e composição da carcaça. Arquivo Brasileiro de Medicina Veterinária e Zootecnia, Belo Horizonte, v. 62, n. 2, p. 439-444, 2010.

FAGUNDES, N. S. Desenvolvimento do sistema digestório e da capacidade digestiva de frangos de corte alimentados com diferentes niveis de energia metabolizável. 2011. Dissertação (Mestrado em Ciências Veterinárias) - Programa de Pós-Graduação em Ciências Veterinárias. Faculdade de Medicina Veterinária. Universidade Federal de Uberlândia, Uberlândia.

FERNANDES, J. I. M.; FREITAG, A.; ROCHADELLI, R.; BURIN, A. M.; CORDEIRO, C. P. Resíduo gorduroso da indústria de óleos vegetais em substituição ao óleo de soja em rações para frangos de corte. Archives of Veterinary Science, Curitiba, v. 7, n. 2, p. 135-141, 2002.

FERREIRA, D. F. Sisvar: a computer statistical analysis system. Ciência e Agrotecnologia, Lavras, v. 35, n. 6, p. 1039-1042, 2011.

GOES, R. H. T. B.; TRAMONTINI, R. C. M.; ALMEIDA, G. D.; CARDIM, S. T.; RIBEIRO, J.; OLIVEIRA, L. A.; MOROTTI, F.; BRABES, K. C. S.; OLIVEIRA, E. R. Degradabilidade ruminal da matéria seca e proteína bruta de diferentes subprodutos agroindustriais utilizados na alimentação de bovinos. Revista Brasileira de Saúde e Produção Animal, Salvador, v. 9, n. 3, p. 715-725, 2008.

INNOCENTINI, R. C. P. Análise dos custos de produção de frangos de corte nos sistemas integrado e independente. Veterinária Notícias, Uberlândia, v. 15. n. 2, p. 9-16, 2009.

LARA, L. J. C.; BAIÃO, N. C.; AGUILAR, C. A. L.; CANÇADO, S. V.; FIUZA, M. A.; RIBEIRO, B. R. C. Rendimento, composição e teor de ácidos graxos da carcaça de frangos de corte alimentados com diferentes fontes lipídicas. Arquivo Brasileiro de Medicina Veterinária e Zootecnia, Belo Horizonte, v. 58, n. 1, p. 108-115, 2006.

MATTERSON, L. D.; POTTER, L. M.; STUTZ, M. W.; SINGSEN, E. P. The metabolizable energy of feed ingredients for chickens. Storrs, Connecticut: The University of Connecticut, Agricultural Experiment Station, 1965. $11 \mathrm{p}$.

OLIVEIRA, R. F. M.; DONZELE, J. L.; ABREU, M. L. T.; FERREIRA, R. A.; VAZ, R. G. M. V.; CELLA, P. $\mathrm{S}$. Efeitos da temperatura e da umidade relativa sobre o desempenho e o rendimento de cortes nobres de frangos de corte de 1 a 49 dias de idade. Revista Brasileira Zootecnia, Viçosa, v. 35, n. 3, p. 797-803, 2006.

PINTO, M. F.; LIMA, V. M. F.; RIBEIRO, S. C.; BOSSOLANI, I. L. C.; PONSANO, E. H. G.; GARCIANETO, M. Fontes de óleo na dieta e sua influência no 
desempenho e na imunidade de frangos de corte. Pesquisa Veterinária Brasileira, Rio de Janeiro, v. 34, n. 5, p. 409414, 2014.

RODRIGUES FILHO, J. A.; AZEVEDO, G. P. C. Instalações zootécnicas. In: VEIGA, J. B. da. (Ed.). Criação de gado leiteiro na Zona Bragantina. Belém: Embrapa Amazônia Oriental, 2006. p. 51-58.

ROSTAGNO, H. S.; ALBINO, L. F. T.; DONZELE, J. L.; GOMES, P. C.; OLIVEIRA, R. F.; LOPES, D. C.; FERREIRA, A. S.; BARRETO, S. L. T.; EUCLIDES, R. F. Tabelas brasileiras para aves e suínos: composição de alimentos e exigências nutricionais. 3. ed. Viçosa: UFV, 2011. 252 p.

SAKOMURA, N. K.; DEL BIANCHI, M.; PIZAURO, J. M.; CAFÉ, M. B.; FREITAS, E. R. Efeito da idade dos frangos de corte sobre a atividade enzimática e digestibilidade dos nutrientes do farelo de soja e da soja integral. Revista Brasileira de Zootecnia, Viçosa, v. 33, n. 4, p. 924-935, 2004.

SIBBALD, I. R.; SLINGER, S. J. A biological assay for metabolizable energy in poultry feed ingredients together with findings which demonstrate some of the problems associated with the evaluation of fats. Poultry Science, Champaign, v. 42, n. 2, p. 313-325, 1963.

VASCONCELLOS, C. H. F.; FONTES, D. O.; LARA, L. J. C.; VIDAL, T. Z. B.; SILVA, M. A.; SILVA, P. C. Determinação da energia metabolizável e balanço de nitrogênio de dietas com diferentes teores de proteína bruta para frangos de corte. Arquivo Brasileiro de Medicina Veterinária e Zootecnia, Belo Horizonte, v. 63, n. 3, p. 659-669, 2011.

VIEIRA, S. L.; RIBEIRO, A. M. L.; KESSLER, A. M.; FERNANDES, L. M.; EBERT, A. R.; EICHNER, G. Utilização da energia de dietas para frangos de corte formuladas com óleo ácido de soja. Revista Brasileira de Ciência Avícola, Campinas, v. 4, n. 2, p. 1-13, 2002.

ZAMBOM, M. A.; SANTOS, G. T.; MODESTO, E. C.; ALCALDE, C. R.; GONÇALVES, G. D.; SILVA, D. C.; SILVA, K. T.; FAUSTINO, J. O. Valor nutricional da casca do grão de soja, farelo de soja, milho moído e farelo de trigo para bovinos. Acta Scientiarum, Maringá, v. 23, n. 4, p. 937-943, 2001. 
